\title{
THE RELIGIOUS INTERACTIONS BETWEEN THE LUWIANS AND ARAMEANS
}

\author{
Luviler ve Aramiler Arasındaki Dinsel Etkileşim
}

\section{Kürşat BARDAKCI*}

\section{ABSTRACT}

Two peoples that stood out with their unique languages in ancient history: Luwian and Arameans. These two peoples with different cultures and origins meet in Northern Syria in the $10^{\text {th }}$ century BC. They mostly acted together against the Assyrian state in the political units known as the Neo-Hittite principalities. Luwians and Arameans decide to live together in this geography rather than conflict. By adopting the Hieroglyphic Luwian, the Arameans used this language especially in monumental buildings. Because, Hieroglyphic Luwian was the most suitable writing for transferring the texts that were desired to be permanent to monumental structures. Similarly, Aramaic reached the Greek world through the Luwians. Thus, Aramaic language has been the common language of agreement of different communities, especially in commercial relations. It is inevitable to experience cultural interactions in the geography where the language spreads. As a matter of fact, the Aramean Moon cult Sin became a very popular cult among the Luwians. Even, the Aramean cult of Sin surpassed the Luwian cult of the Moon, Arma. Apart from this, Luwian cults Tarhu and Runta and Aramaic cults Hadad and Rešeph are seen as equivalents of each other.

Keywords: Luwians, Arameans, Northern Syria, Neo-Hittites, religious interaction.

öz

Antik Çağ'da kendilerine özgü dilleriyle ön plana çıkan iki halk: Luviler ve Aramiler. Farklı köken ve kültüre sahip bu iki halk, M.Ö. 10. yüzyılda Kuzey Suriye'de karşılaşmışlardır. Bu iki halk söz konusu bölgede çatışma yerine birlikte yaşamayı tercih etmişlerdir. Luviler ve Aramiler, Geç-Hitit beylikleri olarak bilinen siyasi birimlerde Asur Devleti'ne karşı çoğunlukla beraber hareket etmişlerdir. Aramiler, bu bölgede Hiyeroglif Luviceyi benimseyerek, özellikle anıtsal yapılarda kullanmışlardır. Çünkü bu dönemde kalıcı olması istenen metinlerin anıtsal yapılara aktarılması için en uygun yazı Hiyeroglif Luviceydi. Benzer şekilde Aramice de Luviler aracılığıyla Yunan dünyasına ulaşmıştır. Böylece Aramice, özellikle ticari ilişkilerde farklı toplulukların

\footnotetext{
* Dr., Ancient Historian, Archaeologist, Turkey. E-mail: kbrdkci@gmail.com. ORCID: 0000-00017893-4434. 
ortak anlaşma dili olmuştur. Dilin yayıldığı bir yerde kültürel etkileşimlerin yaşanması kaçınılmazdır. Nitekim Arami Ay kültü Sin, Luviler arasında çok popüler bir kült haline gelmiştir. Hatta Arami Ay kültü Sin, Luvi Ay kültü Arma’yı geride bırakmıştır. Bunun dışında Luvi kültleri Tarhu ve Runta ile Arami kültleri Hadad ve Rešeph birbirlerinin muadili olarak görülmektedir.

Anahtar Sözcükler: Luviler, Aramiler, Kuzey Suriye, Geç Hititler, dini etkileşim.

\section{Introduction}

In the $1^{\text {st }}$ millennium BC, the terms "Neo-Hittite", "Late-Hittite", and "Syro-Hittite" are mostly used to describe the civilization of Luwian and Aramaic speaking centers. The reason for this is that no clear stylistic distinction can be made in the art and architectural styles of these two peoples. Although they are common adjectives to define the Luwian and Aramean centers, these terms are still controversial (Aro, 2003: 281-282). So much so that there are also principalities in Central Anatolia consisting entirely of the Luwian people. In addition, there are principalities in Northern Syria with a predominantly Hurrian population. On the other hand, one of the reasons for using different terms for the region is that little is known about the political organization of these principalities (Van de Mieroop, 2007: 218). While kings with Luwian names were ruling in these principalities, kings of Aramaic origin could suddenly replace them. At the same time, the names of principalities and cities of some Luwian origin were also changing and taking Aramaic names.

The fact that the Northern Syria is called "Hatti and Aram" in the Assyrian annals shows that there is a difference between the Hittite-linked states and the Aramean states. However, these nomenclatures are also ambiguous. As a matter of fact, Assyrians used the term Hatti in general to describe the west together with the Aramean and Phoenician states and sometimes to describe the Northern Levant (Kuhrt, 1995: 411). For instance, when Sargon captured the Aramaic kingdom of Hamath, he described Yahu-bihdi, king of Hamath, as a "damned Hittite" (Oppenheim, 1969: 285).

Another problem is that Aramaic writings have not survived. As a matter of fact, since the Arameans wrote on papyrus and parchment, all records of the daily activities disappeared over time. Papyrus and parchment were not durable materials, and the climate of the region was not suitable for their preservation. Only a few monumental inscriptions carved into stone remain today. There are also some problems for Hieroglyphic Luwian. It is 
known that syllable signs were used with many variants in Hieroglyphic Luwian writing. ${ }^{1}$ A single sign can have many different forms (Gelb, 1931: 6). These syllable signs must be determined one by one. This causes some uncertainties about the sequence of signs. So, there were serious misunderstandings in the resolution of some inscriptions. Cuneiform Luwian texts, however, are extremely limited. At the same time, it is sometimes difficult to decide whether a particular form is Luwian or Hittite (Friedrich, 2000: 116-117). Despite all this, the value of the inscriptions found in the region cannot be denied. These inscriptions provide very important information in terms of both political and cultural history.

\section{Luwians and Arameans}

Several provisions of the Hittite Laws assure us that in the middle of the $2^{\text {nd }}$ millennium BC there was in Anatolia a land Luwiya (KUR ${ }^{(U R U)}$ Lu-ú-i-ya). The "Land Luwiya" appears to be an Old Hittite ethno-linguistic term referring to the area where Luwian was spoken (Hawkins, 2013: 30-32). However, questions such as where and why the Luwians came from and how they call themselves, who settled in Anatolia from the end of the $3^{\text {rd }}$ millennium $\mathrm{BC}$ remain a mystery. When the Luwians of Indo-European origin came to Anatolia, they settled in the south of Anatolia; especially organized in Tarhuntašša and Kizzuwatna (Bryce, 2003: 88). After the collapse of the Hittite state, the Luwians migrated to the east and southeast, where they defined themselves as the successors of the Hittites and established a series of principalities -Neo-Hittite principalities- (Van de Mieroop, 2007: 218). During the migration movements of the Luwians, Arameans also started to infiltrate the entire Near East, leaving the Syrian-Arabian deserts.

The origin of the Semitic Arameans is thought to be from Aram, son of Shem, Noah's grandson, and dates back to $3^{\text {rd }}$ millennium BC (Potts, 1881: 231). The word "Aram", as the name of a region or of a state, first appears, in a cuneiform inscription of the Akkadian king Naram-Sin (2254-2218 BC); from the context this Aram would seem to be situated in Upper Mesopotamia. The interpretation of this inscription is not absolutely certain; but a new mention of "Aram" is to be found soon afterwards on a tablet from the commercial archives of Drehem (ancient Puzriš-Dagan), belonging to about 2000 BC, and referring to a city and a state near Ešnunna, on the lower Tigris. Another Drehem tablet contains the personnel name Aramu, and the same name is found again in a Mari text dating back to 1700 BC. An in-

\footnotetext{
${ }^{1}$ For Hieroglyphic Luwian records, see. (Yıldırım, 2018).
} 
scription of the Assyrian king Arik-den-ilu speaks of victories over the hosts of the "Akhlamu", and this name reappears under subsequent kings, until Tiglath-pilesser I (1114-1074 BC) announces that he has routed the Akhlamu-Arameans who came from the desert to infest the banks of the Euphrates. After Tiglath-pilesser I there are several other references in Assyrian sources to Akhlamu and Akhlamu-Arameans, but the simple term "Arameans" becomes more and more usual, and finally is the only one in use (Moscati, 1960: 168-169). During the mentioned periods, the Arameans spread over a wide geography from Mesopotamia to the Eastern Mediterranean. They kept their tribal organization and were subdivided into groups identified as belonging to the "house of so-and-so", in Akkadian "Bit" and the name of a person, who was considered to be the tribal ancestor. Some of the states they founded were referred to in the $1^{\text {st }}$ millennium by this designation, for instance Bit-Adini. In Northern Syria, Arameans took control of many cities, including some that were inhabited by people who maintained Hittite cultural and political traditions (Van de Mieroop, 2007: 204).

Arameans, when they infiltrated Northern Syria in the $10^{\text {th }}$ century BC, they encountered people using Hieroglyphic Luwian. These principalities in Northern Syria used Hieroglyphic Luwian: Carchemish, Melid, Kummuh, Gurgum, Masuwari (Aramaic Til Barsip), Pattina (Aramaic Unqi), Sam'al (Aramaic Y'DY), Hamath and Arpad (Younger, 2016: 30). The principalities mentioned had a mixed population. Luwians and Arameans constituted the majority of this population. In addition, as it is understood from the kings with Hurrian names in some principalities, Hurrians also lived in these principalities. Moreover, peoples such as Kaškaeans and Phrygians were also involved in these principalities. Thus, Northern Syria in the $10^{\text {th }}$ century BC, it had become a multicultural region where people from many different cultures interacted closely. With the Luwians and Arameans starting to live together in the region, it is seen that there is an intense interaction between the two cultures in many areas from language to religion. This interaction can be most clearly observed in the belief system. Before going into this subject, it will be useful to talk about the belief systems of the two peoples. There will be no detailed explanation here. Only the belief structures within the scope of our study will be briefly mentioned.

\section{A General Look at Luwian Religion}

Almost all cuneiform texts related to the Luwian religion come from the Hittite capital, Hattuša, not from the Luwian lands (Bawanypeck, 2013: 159). "Maššan(i)" is the general Luwian word for god. This name and names 
derived from it are used in the sense of "god/deity" or "divine" (Masson, 1991: 673). The most important Luwian god is the Storm god Tarhu(nt). Hittites and Hurrians (Tešup) also worshipped Tarhu. In order for the Tarhu to bring blessings, ripen the grapes and protect the vineyards, a festival was held accompanied by Luwian songs and talismans, and sacrifices were present to Tarhu. Indeed, abundance was generally associated with the Storm god, who brought rain through lightning and thunder. Another Luwian god to be mentioned in the study is Santa, who is probably the god of War. As a War god or warrior, Santa can be dangerous to his enemies, and thus his name is thought to derive from the Luwian "šā(i)" - "to be(come) angry". In general, his strength is positive for his followers. Runta/Runtiya, on the other hand, is a Luwian Guardian god, similar to the characters of war or hunting gods. Runta, the deer is closely related to the bow and arrow. For this reason, it is also referred to as the "Deer god". It is understood from the $\mathrm{Hi}$ eroglyphic Luwian inscriptions that it is not only protective but also rewarding. The Luwian Moon god is Arma. His worship is almost exclusively limited to the Luwians. He was worshiped mostly in Tarhuntašša (Hutter, 2003: 219-229). The rituals to facilitate pregnancy or birth are performed for Ar$\mathrm{ma}$, the Moon god, and sometimes the problems caused by Arma are also mentioned. The "Pittei birth ritual" of Luwians is not only related to birth, but also a ceremony associated with the moon. Some scientists think that this ceremony was held during the lunar eclipse. ${ }^{2}$ However, this ritual was performed at the time of the birth of Pittei's patient to counter the sign of evil indicated by a rising red moon. In this ritual, the moon is depicted in a frightening way. There are parallels of this ritual in Hittite, Hattian and Akkadian (Bacharova, 2013: 135-141, 155).

Luwian rituals were held in open areas such as mountains and springs. Due to the mountainous geographical structure, the Luwians were far from the understanding of architectural temples. No Luwian temple has been detected so far. It is thought that only the stele building on Kilise Tepe could be a Luwian temple. However, it is currently not correct to describe this place as a Luwian temple with certainty (Postgate \& Stone, 2013). On the other hand, ÇiFTLiK and KULULU 5 in Tabal principality in middle Anatolia Hieroglyphic Luwian inscriptions middle $8^{\text {th }}$ century BC, mentioned "houses" built for important gods (Hawkins, 2000: 431). These houses can also be temples in a sense. However, the temple is not just about advanced archi-

\footnotetext{
${ }^{2}$ See (Giorgieri, 2004).
} 
tectural sites. Apart from mountains and water sources, sometimes a stone, tree or any region can serve as a temple (Demirci, 2017: 79). Mountains and rivers, where mostly rituals were performed for the Luwians, served as temples.

\section{A General Look at Aramean Religion}

The Aramean religion, like all the beliefs of the ancient Near East, derives its characteristic from the coexistence of the official religion and the folk religion. In addition, Arameans were influenced by the beliefs of other nations, as they did not have a common culture. In general, the influence of Mesopotamia and Canaan is seen in the Aramean belief system (Köroğlu, 2012: 148). The Arameans immediately adopted the new beliefs they encountered in the said regions. For example, when the Arameans settled in the Harran region, they encountered the cult of the Moon god Sin. Harran was the cult center of the Sin cult. As a matter of fact, the cult of the moon occupied an important place in Urfa and Harran in ancient Anatolia (Demirci, 2017: 32). ${ }^{3}$ The Arameans also adopted this cult and identified it with their god "Śahr" and shortened it as "Ši"” (Lipinski, 1994: 174; Niehr, 2014: 133).

In ancient times, the cult of the moon is a legacy of a tradition formed by the lifestyle of nomadic peoples such as the Arameans. As a matter of fact, nomads believed that there was a mysterious relationship between man and the moon due to the moon's illuminating feature at night and the spontaneous existence and disappearance of the full moon and the crescent. According to belief, Sin is not the god of the moon or a god sitting on the moon. It was believed that Sin manifested especially in the moon. However, the moon in which Sin is manifested is Sin itself, and the moon becomes god. The "kispum" ritual, originating from Mesopotamia is also associated with the cult of the moon. Apart from the moon cult, it is also related to the cult of ancestors. As a matter of fact, the kispum ritual served to appease the spirits of it was deceased ancestors and was performed twice a month. In this ritual, the names of the deceased were mentioned and the continuity of their lives in the next world it was ensured. Also, when the moon was dark, it was considered ominous, and some taboo rituals of the moon were performed during these periods (Demirci, 2017: 22-23, 31-32). The belief about the sinister and evil aspect of the moon, as will be remembered, was also valid for the Luwians.

\footnotetext{
${ }^{3}$ See also (Green, 1992).
} 
The religion of the state and the religion of the people were united in Baal. The official lord of each city or kingdom and protector of the city is Baal, its lady is "Bacalat" (Van der Toorn et al., 1998: 132-140). For example, "My lord, Baal of Harran" text is visible in "Bar-rākib and his scribe" Aramaic inscription in Sam'al. Also, it is known that Luwian cult Santa was associated with Baal of Tarsos by the Arameans (Hutter, 2003: 229). Baal and Baalat of each kingdom were not only the guardians of the country, but also the gods of vegetation and fertility. The Aramean Storm god Hadad is associated with Baal. If Baal and Hadad refer back to the same deity, however, it must be admitted that, in the $1^{\text {st }}$ millennium $B C$, the two names came to stand for distinct deities: Hadad being a god of the Arameans, and Baal a god of the Phoenicians and the Canaanites (Van der Toorn et al., 1998: 132). As understood from the tomb steles (Panamuwa and Katimuwa) the Arameans were performing rituals for the Storm god Hadad and offering sacrifices to him. But these rituals are not clear. There have been attempts to explain it as a substitution rite following Hittite royal ancestor cult in which the transgressions of the deceased are transferred to an animal (Niehr, 2014: 129; 188). As for Rešeph is generally seen as the god of epidemic and sudden death. However, it also has different features and tasks (Lipinski, 2009).

Unlike the Luwians, the Arameans had an architectural understanding of temple. As a matter of fact, the existence of temples built by the Arameans in Syria is known. Among the most well-known of these structures is the "Ain Dara" temple (Assaf, 1990). Also, the "Hieros gamos" ritual (holy marriage), which was performed once a year at the New Year's celebration (the "Akitu" holiday) in the spring, was performed in the ziggurats, such as of Harran Castle ziggurat. These ziggurats were seen as places where gods and humans met. The public could not participate in this ritual. As a matter of fact, this ceremony is it was performed with the king and a nun; Thus, the well-being of the people and the city it was believed to be provided (Hrouda, 2005: 105; Demirci, 2017: 88). At the same time, the sanctity of the mountains was also valid for the Arameans. As a matter of fact, in almost all of the ancient civilizations, it was thought that some gods sited on the mountain.

\section{Luwian-Aramean Religious Acculturation}

The earliest data on Luwian-Aramean interaction comes from Hamath. Urahilina, one of the Luwian origin kings who ruled in Hamath in the $9^{\text {th }}$ century $\mathrm{BC}$, mentions a donation to a temple endowment to the goddess 
Baalat in an inscription. It is understood that the temple existed during the time of Urahilina's father and grandfather, but they were not interested in the temple and Baalat. Also in this inscription, Urahilina damnes (possibly) with Tarhu against those who erase the name of herself and Baalat. The emphasis on Tarhu instead of Baalat's wife Baal shows the religious globalization in the region:

I'm Urahilina, son of Paritas, king of Hama... And I made his own seat for every single god. But this seat I built for Baalat, and I my put name and Baalat's (on it). But who(soever) shall take away my name and Baalat's from this seat, but after (?), the Storm god Tarhunzas [...]. During the time of my father and grandfather, the temple of Baalat lacked income. They did not burn the burnt offering, a sacrificial ox, up and down to the god. But (as regards) myself, in my times, it shall not lack income. Time and time, I offered to it MUHA and offerings... (HAMA 4; Payne, 2012: 65).

More information about the interaction belief interaction between Luwians and Arameans ${ }^{4}$ comes from Tabal. The Aramean people in Tabal could not establish a political union, however, Aramean culture spread to this region through the Bit-Brutaš tribe. Hieroglyphic Luwian inscriptions unearthed in Tabal are found in the region; especially it gives some information about the belief system in the second half of the $8^{\text {th }}$ century BC. Luwian-Aramean belief interaction can be seen especially in funeral inscriptions and god lists. In one of the funerary inscriptions dated to the middle of the $8^{\text {th }}$ century $\mathrm{BC}$, the theme of a funeral cult prepared in memory of Panuni was mentioned. Here Panuni die while eating and drinking with the Luwian cult Santa: "I (am) Panunis, the Sun-blessed prince. For me my children made here a sealed (?) document (?). On my bed(s) eating (and) drinking (?)... by the god Santas I died" (KULULU 2; Hawkins, 2000: 488).

We encounter a similar theme in the inscriptions found in Sam'al (Zincirli). For example, about in connection with the offerings made by king Panamuwa to the Aramean Storm god Hadad, dated to $750 \mathrm{BC}$, in Gerçin (about 6-7 km. northeast of Zincirli) found on the Sam'alian ${ }^{5}$ funeral in-

\footnotetext{
${ }^{4}$ For Luwi-Aramean cultural interaction, see also (Yıldırım, 2016).

${ }^{5}$ One of the languages used in Sam'al principality. There is still no consensus on the classification of Sam'alian. The three main classification theories are as follows: Sam'alian as an archaic form of Aramaic; Sam'alian as a hybrid of Aramaic, and Canaanite and Sam'alian as a unique Northwest Semitic language (Noorlander, 2012: 203).
} 
scription "eating and drinking of the soul with Hadad" theme Luwians and Arameans between shows that there is an interaction:

I'm Panamuwa, son of Qarli, king of Y'DY, who have erected this statue for Hadad in my eternal abode (burial chamber) ... [whoev]er of my sons (descendants) seizes the scepter, and sits on my throne, and reigns over $Y^{\prime}[D Y]$, and maintains his power, and sacri[fices to his Hadad], [and does not remem] ber the name of Panamuwa, (who) does (not) say: 'May the dead spirit of Pana[muwa] eat with Hadad, and may the dead spirit of Panamuwa drink with $\mathrm{H}\left[\mathrm{adad}^{\prime}\right]$; then [...] his sacrifice... (Younger, 2003: 156-158).

In addition, the emphasis on the relationship between the Storm God and the vineyards in some tomb steles is also an important evidence of the belief interaction between Luwians and Arameans. The belief about the relationship of the Storm god with grape and grain it appears in some inscriptions from the $8^{\text {th }}$ century BC. For example, in a hieroglyphic inscription found in Sultanhanı in Tabal, the following expressions are mentioned: "I set up this Tarhunt of the vineyard (saying): ... Tarhunt shall make his vineyard grow, and the vine shall grow" (SULTANHANI 2; Hawkins, 2000: 465).

The relationship between the god believed to be Tarhu in the Luwians and the vineyards is valid for Hadad in the Arameans. For example, on the Sam'alian tomb stele of Sam'al royal officer Katimuwa (KTMW) found in Sam'al, dated approximately 735 BC, the relationship between Hadad and vineyards is seen. Sacrifices are also offered to "Hadad of the vineyards": "I'm KTMW, servant of Panamuwa, who commissioned for myself (this) stele while still living. I placed in my eternal chamber and established a feast (at) this chamber: ... a ram for Hadad of the vineyards, a ram for Kubaba..." (Pardee, 2009: 53-54).

Another evidence of the faith interaction between Luwians and Arameans is the god lists found in Tabal. So much so that in the middle of the $8^{\text {th }}$ century BC, many inscriptions found in many places in the Tabal region, such as Kululu, Bulgarmaden, Karaburun, refer to the Moon god of Harran. According to these inscriptions, Semitic and Hurrian, such as Ea and Kubaba, members joining the Luwian pantheon, but Tarhu of Luwian retained his superior position. These inscriptions are among the clearest evidences of the globalization experienced in this period. For example: 
Here Tarhunzas and Hepat sit(s), [and here] Ea and Ku[baba] sit(s), and here Sarrumas and Alasuwas sit(s)... For Tuwatis may also these gods come well, and to him to eat and to drink, and to him life of person (lit., head) may they give, and to him long days, (may) all the gods give this to him! [...] Tarhunzas [...] and I mysef built myself a house (ÇiFTLiK; Hawkins, 2000: 449). The gods Tarhunzas, Hiputas (Hepat), [Ea], Kubaba, Haranean Sarmas (Šarruma of Harran), Alasuwas, in the city Harmana, Haranean Moon-god (Sin), the Sun-god ..., [...] house-lord these houses [...] they gave them to Hulasayas the sun-blessed prince here" (KULULU 5; Hawkins, 2000: 485).

These references refer to the Moon god (Sin) of the Harran Aramean cult in Anatolia. This indicates that they were worshiped in remote areas (Lipinski, 1994: 182). In fact, the Moon god from Harran entered Central Anatolia during the Hittite empire and became very popular among the Hittites (Yakubovich, 2013: 105). However, at that time, the Luwians did not worship the Harran Moon god. In the $1^{\text {st }}$ millennium BC, the Moon god of Harran became so famous that this cult overshadowed the Luwian god Arma. The Arma clearly lost power against the Moon god of Harran (Hutter, 2003: 273). On the other hand, according to the expression "Haranean Sarmas (Šarruma)" the Hurrian cult Šarruma was adopted by the Arameans and named together with the city of Harran.

Apart from all these, the Karatepe-Aslantaş Hieroglyphic LuwianPhoenician bilingual inscription is an important source provides information about the belief system in the period. In this inscription, Luwian Tarhu (Tarhunzas) and Aramean Baal; The Luwian Runta (Runzas) and the Rešeph of the Aramean goats are stated as equivalent gods of each other. Rešeph's equation with Runzas shows that he also has a protective feature. Also, Ea and Tarhu are used together, and Tarhu is again supreme. As it is understood, Azatiwatas speaks to peoples in the region:

I'm Azatiwatas, the Sun-blessed man, Tarhunza's (Baal in Phoenician text) servant, whom Awarikus, king of Adanawa, made great. Tarhunzas made me mother and father to Adanawa, and I caused Adanawa to prosper, and I extended the Adanawa plain on the one hand towards the west and on the other hand towards the east, and in my days Adanawa had all good things, plentiness, and luxury... I built this fortress, and I named it Azatiwataya. So Tarhunzas and Runtiyas (Rešeph-SPRM; Rešeph-of-the-goats in Phoenician 
text) were after me to build this fortress, and I built it [with (the help of) Tarhunzas...] in my days [...]... If anyone from the kings, or (if) he (is) a man, and he has a manly name, speaks this: "I shall delete the name of Azatiwatas from these gates here, and I shall carve in my name," or (if) he desires this fortress, and blocks up these gates, which Azatiwatas made, and speaks thus: "I shall make these gates mine, and I shall write my own name (on them)." Or (if) from desire he shall block them up, or from badness or from evil he shall block up these gates, may celestial Tarhunzas, the celestial Sun, Ea and all the gods delete that kingdom and that king and that man! In future, may Azatiwatas' name continue to stand for all ages, as the name of the Moon and of the Sun stands! (Bossert, 1948; Çambel, 1999; Hawkins, 2000; Payne, 2012).

\section{Conclusion}

Northern Syria has had a very important position throughout history, as it is a geography where different cultures live together. In the $1^{\text {st }}$ millennium $\mathrm{BC}$, the region hosted many different cultures such as Luwian, Aramean, Phoenician and Hurrian. These peoples lived together in the Neo Hittite principalities. This has caused a cultural interaction between peoples. Such that, Hieroglyphic Luwian and Sam'alian/Aramaic inscriptions found in $\mathrm{Ha}-$ math, Tabal and Sam'al reveal the belief interaction between the Luwians and Arameans. Luwian-Aramean interaction can be clearly seen, especially in funerary inscriptions and god lists. So much so that many inscriptions found in settlements such as Kululu, Bulgarmaden, and Karaburun in Tabal refer to the Moon god of Harran. According to these inscriptions, the Moon god of Harran entered the Luwian pantheon, even surpassing the Luwian Moon god Arma. In addition, the Azatiwatas inscription shows the Luwian cults Tarhu and Runta as the counterparts of the Aramean cults Hadad and Rešeph. In addition, the relationship between Hadad and Tarhu with vineyards is the same. Similar themes are found in the funerary inscriptions at Tabal and Sam'al.

\section{References}

Aro, Sanna (2003). "Art and Architecture". The Luwians. Ed. H. Craig Melchert. Leiden: Brill, 281-337. 
Assaf, A. Abu (1990). Der Tempel von 'Ain Dara. Mainz: Verlag Philipp von Zabern.

Bachvarova, Mary R. (2013). "CTH 767.7 The Birth Ritual of Pittei: Its Occasion and the Use of Luwianisms". Luwian Identities: Culture, Language and Religion Between Anatolia and the Aegean. Eds. Alice Mouton and the others. Leiden: Brill, 135-158.

Bawanypeck, Daliah (2013). "Luwian Religious Texts in the Archives of Hattuša”. Luwian Identities: Culture, Language and Religion Between Anatolia and the Aegean. Eds. Alice Mouton and the others. Leiden: Brill, 159-176.

Bossert, Helmuth Th. (1948). "Die Phönizisch-Hethitischen Bilinguen vom Karatepe". Belleten, 12: 523-531.

Bryce, Trevor R. (2003). "History". The Luwians. Ed. H. Craig Melchert. Leiden: Brill, 27-127.

Çambel, Halet (1999). Corpus of Hieroglyphic Luwian Inscriptions, Vol. 2, Karatepe-Aslantas. The Inscriptions: Facsimile Edition. Berlin: Walter de Gruyter.

Demirci, Kürşat (2017). Eski Mezopotamya Dinlerine Giriş, Tanrılar, Ritüel, Tapınak. İstanbul: Ayışığı Kitapları.

Friedrich, Johannes (2000). Kayıp Yazılar ve Diller. Trans. R. Tekoğlu. İstanbul: Arkeoloji ve Sanat Yayınları.

Gelb, Ignace J. (1931). Hittite Hieroglyphs I. Chicago: The University of Chicago Press.

Giorgieri, Mauro (2004). "Das Beschwörungsritual der Pittei”. Orientalia Nova Series, 35: 409-426.

Green, Tamara M. (1992). The City of the Moon God: Religious Traditions of Harran. Leiden: Brill.

Hawkins, J. David (2000). Corpus of Hieroglyphic Luwian Inscriptions, Vol. 1, Inscription of the Iron Age. Berlin: Walter de Gruyter.

Hawkins, J. David (2013). "Luwians versus Hittites". Luwian Identities: Culture, Language and Religion Between Anatolia and the Aegean. Eds. Alice Mouton and the others. Leiden: Brill, 25-40.

Hrouda, Barthel (2005), Mesopotamien. München: Verlag C. H. Beck.

Hutter, Manfred (2003). “Aspects of Luwian Religion”. The Luwians. Ed. Melchert, H. Craig Melchert. Leiden: Brill, 211-280. 
Köroğlu, Kemalettin (2002). Eski Mezopotamya Tarihi. İstanbul: iletişim Yayınları.

Kuhrt, Ameline (1995). The Ancient Near East, c. 3000-330 B.C. II. London: Routledge.

Lipinski, Edward (1994). Studies in Aramaic Inscriptions and Onomastics. Leuven: Peeters.

Lipinski, Edward (2009). Resheph: A Syro-Canaaite Deity. Leuven: Peeters.

Masson, Olivier (1991). "Anatolian Languages". The Cambridge Ancient History III/2. Eds. J. Boardman and the others. New York: Cambridge University Press, 666-676.

Moscati, Sabatino (1960). Ancient Semitic Civilizations. New York: Capricorn Books.

Niehr, Herbert (2014). "Religion". The Arameans in Ancient Syria. Ed. Herbert Niehr. Leiden: Brill, 127-204.

Noorlander, Paul (2012). "Sam'alian in its Northwest Semitic Setting: A Historical-Comparative Approach”. Orientalia, 81: 202-238.

Oppenheim, A. Leo (1969). "Babylonian and Assyrian Historical Texts". Ancient Near Eastern Texts Relating to the Old Testament. Ed. James B. Pritchard. Princeton, New Jersey: Princeton University Press, 265-317.

Pardee, Dennis (2009). "A New Aramaic Inscription from Zincirli”. Bulletin of the American Schools of Oriental Research, 356: 51-71.

Payne, Annick (2012). Iron Age Hieroglyphic Luwian Inscriptions. Atlanta: SBL Press.

Postgate, Nicholas \& Stone, Adam (2013). "A Luwian Shrine? The Stele Building at Kilise Tepe". Luwian Identities: Culture, Language and Religion Between Anatolia and the Aegean. Eds. Alice Mouton and the others. Leiden: Brill, 193-214.

Potts, John F. (1981). The Swedenborg Concordance I. London: Swedenborg Society.

Van de Mieroop, Marc (2007). A History of the Ancient Near East. Oxford: Blackwell Publishing.

Van der Toorn, Karel and the others (eds.) (1998). Dictionary of Deities and Demons in the Bible. Leiden: Brill.

Yakubovich, Ilya (2013). "Anatolian Names in - wiya and the Structure of Empire Luwian Onomastics". Luwian Identities: Culture, Language and 
Religion Between Anatolia and the Aegean. Eds. Alice Mouton and the others. Leiden: Brill, 87-124.

Yıldırım, Nurgül (2016). "Çiviyazılı Kaynaklara Göre Patina Krallığı'ndan Unqi Krallığı'na Antakya ve Amik Ovası'nın Tarihsel Süreci”. Belleten, 80(289): 701-718.

Yıldırım, Nurgül (2018). "Demir Çağı Kent Devletleri Döneminde Sam'al Ve Yakın Çevresinde Kullanılan Luvice ve Sam'alca Kayıtlar Üzerine Genel Bir Değerlendirme". Cappadocia Journal of History and Social Sciences, 10: 163-178.

Younger, K. Lawson (2003). "The Hadad Inscription (2.36)". Ed. W. Hallo. The Context of Scripture II. Leiden: Brill, 156-158.

Younger, K. Lawson (2016). A Political History of the Arameans: From Their Origins to the End of Their Polities. Atlanta: SBL Press.

The following statements are made in the framework of "COPE-Code of Conduct and Best Practices Guidelines for Journal Editors":

Ethics Committee Approval: Ethics committee approval is not required for this study.

Declaration of Conflicting Interests: The author has no potential conflict of interest regarding research, authorship or publication of this article. 